\title{
Labyrinthe
}

31 | 2008 (3)

Revues modes d'emploi

\section{Traductions en revues}

\section{(2) OpenEdition}

1 Journals

Édition électronique

URL : http://journals.openedition.org/labyrinthe/3871

DOI : 10.4000/labyrinthe.3871

ISSN : 1950-6031

Éditeur

Hermann

Édition imprimée

Date de publication : 15 octobre 2008

ISBN : 978-2-9526131-8-7

Référence électronique

«Traductions en revues », Labyrinthe [En ligne], 31 | 2008 (3), mis en ligne le 08 novembre 2008, consulté le 20 avril 2019. URL : http://journals.openedition.org/labyrinthe/3871 ; DOI : 10.4000/ labyrinthe.3871

Ce document a été généré automatiquement le 20 avril 2019.

Propriété intellectuelle 


\section{Traductions en revues}

